\title{
EFEKTIVITAS PEMBERIAN CGF 40\% DALAM MEMPERCEPAT PENINGKATAN TROMBOSIT PADA PENDERITA DEMAM BERDARAH DENGUE
}

\author{
(Effectiveness of CGF 40\% in Hastening the Increasing of Thrombocyte in Dengue Fever Patient)
}

Adi Teruna Effendi ${ }^{1 * 2}$, Sediono $\mathrm{M}^{1}$, Suksmono $\mathrm{HS}^{1}$, Erwanto $\mathrm{B}^{1}$, Yekti Hartati Effendi ${ }^{3}$, Mira Dewi ${ }^{3}$, dan Darwin Karyadi ${ }^{3}$

\footnotetext{
1 Departemen Penyakit Dalam, Rumah Sakit Karya Bhakti, Bogor

2 Fakultas Pasca Sarjana, Institut Pertanian Bogor, Bogor 16680

3 Departemen Gizi Masyarakat, Fakultas Ekologi Manusia (FEMA), Institut Pertanian Bogor, Bogor 16680.

* Alamat korespondensi: Departemen Penyakit Dalam, Rumah Sakit Karya Bhakti, Bogor

Email: ate_effendi@yahoo.com
}

\begin{abstract}
Aim of this study was to evaluate the effectiveness of CGF $40 \%$ in hastening the recuperation, as indicated by reduced length of hospital stay, improvement in clinical status, increase in platelets, and reduction in the hemoconcentration. The study group comprised of 84 consecutive DHF patients, 42 male and 42 female subjects, who were randomized into the control group receiving the WHO standard therapy and the intervention group receiving CGF $40 \%$ and the standard therapy. Hemoglobin, hematocrite and thrombocyte counts were taken daily until the subjects were free of the symptoms and signs of DHF, and the thrombocyte count read $>100.000$. The results were analyzed statistically, student $t$ test and quadratic regression, using SPSS 16 software. The average length of recuperation time in the intervention and control groups were 2.76 days and 4.43 days respectively $(p=0.000)$. Recuperation times of subjects with thrombocyte counts $<50,000$ and $>50,000$ of the intervention group (3,09 and 2,37 days) and the control group (4,2 and 4,5 days) were different significantly $(p=0.016$ and 0.000$)$. When analized specifically in the treatment group, the recuperation time of those with thrombocyte counts $<50,000 \mathrm{U}$ (2.37 days) did not differ to those with $>50,000$ (3.09 days) with $p=0.112$. Using quadratic regression, the increase in thrombocytes, reduction in hemoglobin concentrations and hematocrite were faster in the intervention group when compared to the control group, with $R^{2}$ almost reaching 1. The study disclosed that administration of CGF 40\% could reduce the recuperation time and improved the hemoconcentration, which presumably demonstrated the concept of regenerative medicine as indicated by the repairmen of vascular permeability.
\end{abstract}

Key words: Chlorella Growth Factors (CGF), green algae, dengue fever, and regenerative medicine.

\section{PENDAHULUAN}

Dengue adalah homonim dari bahasa Afrika, ki denga pepo, suatu penyakit yang pernah mewabah di wilayah Karibia, Amerika Tengah, pada tahun 1827 - 1828. Kini demam tersebut dikenal dengan nama Demam Dengue (DD) (Anonim, 2009), penyakit viral transmisi nyamuk Aedes Aegypti yang tersebar luas di antara garis lintang Utara $35^{\circ}$ dan Selatan $35^{\circ}$. Di Indonesia Demam Dengue (DD) telah menjadi wabah musiman sejak tahun 1968, bahkan hingga kini masih saja menimbulkan masalah kesehatan nasional. Pada tahun 1998 ter jadi wabah DD di Indonesia yang menyerang hingga sejumlah 58.000 penderita.
DD disebabkan oleh infeksi VDEN, tergolong famili Flaviviridae, dan genus Flavivirus yang secara antigenik dibedakan atas empat jenis serotipe, yaitu DEN-1, DEN-2, DEN-3 dan DEN-4. DEN 2 dan DEN 1 dilaporkan memiliki tingkat virulensi yang dapat menimbulkan DBD yang lebih berat. Di Indonesia keberadaan keempat serotipe tersebut pernah diidentifikasi tepatnya ketika terjadi epidemi DD di Bandung (Porter et al., 2005).

Pada dasarnya DD merupakan penyakit yang bersifat self-limited, namun Infeksi VDEN dalam dinamikanya tak jarang menimbulkan ragam gambaran klinik, seperti demam Dengue (DD), demam berdarah Dengue (DBD disertai gangguan perdarahan), bahkan potensial berkembang menjadi katastrofik (Sindroma Ren- 
jatan Dengue SRD) (Rigau-Perez et al., 1998).

Gambaran klinik DD pada awalnya ditandai oleh demam tinggi yang timbul secara akut. Di samping itu dapat pula disertai oleh petekiae, sakit kepala, mialgia, nyeri tulang dan sendi, nausea, nyeri epigastrik, bahkan diare. Pada DD secara tipikal ditandai oleh adanya trombositopenia (hitung trombosit < $100.000 / \mu \mathrm{L})$, serta perembesan vaskuler yaitu plasma merembes ke ruang antar jaringan (Saito et al., 2004), yang secara klinik ditandai oleh hemokonsentrasi, berupa peningkatan hematokrit sedikitnya $20 \%$ serta peningkatan kadar hemoglobin darah, efusi pleural atau hipoalbuminemia. Perembesan vaskuler tersebut dapat menimbulkan gagal sirkulasi, seperti renjatan yang potensial berkembang menjadi sindroma renjatan Dengue (SRD) yang bersifat katastrofik (Guzman \& Kouri, 2002; Kuo et al., 2007).

Akan tetapi tidak semua infeksi VDEN serta-merta menimbulkan gejala demam, seperti yang terungkap melalui satu penelitian prospektif dengan subjek mahasiswa, sejumlah 13\% yang menunjukkan gejala demam, sedangkan sisanya sejumlah $87 \%$ lagi bersifat asimtomatik atau kalau pun ada hanya bersifat simtomatik ringan (Burke et al., 1988). Fenomena tersebut tentu memberikan sinyal adanya kemungkinan faktor tingkat imunitas hospes yang berperan dalam penentuan sebaran DD.

Gizi seimbang adalah faktor utama yang diperlukan untuk mengoptimalkan regenerasi sel. Suplemen makanan merupakan pilihan untuk melengkapi kebutuhan gizi yang saat ini secara kualitas dan kuantitas semakin sulit dipenuhi dari makanan sehari-hari, terlebih pada keadaan sakit seperti DD di mana terjadi penurunan nafsu makan, mual dan muntah. Chlorella Growth Factor (CGF) adalah komponen gizi yang terdapat pada ganggang chlorella. CGF mengandung berbagai zat gizi lengkap yang secara alami mampu mengoptimalkan pertumbuhan sel, meningkatkan sistem kekebalan tubuh serta mempercepat penyembuhan luka. Dengan memperhatikan manfaat CGF di atas, diharapkan CGF dapat mempercepat proses penyembuhan, khususnya dalam meningkatkan jumlah trombosit serta memperbaiki permeabilitas vaskuler.

Pada penelitian ini dilakukan uji klinik guna menentukan efektivitas pemberian CGF khususnya dalam memperbaiki perembesan vaskuler, sehingga dapat mempercepat per- baikan klinik yang secara tipikal ditunjukkan oleh peningkatan jumlah trombosit serta penurunan hemokonsentrasi. Di samping itu diharapkan CGF dapat memperpendek hari perawatan penedrita DD. Tujuan penelitian ini adalah menilai efektivitas pemberian CGF $40 \%$ dalam mempercepat pemulihan/masa penyembuhan pada penderita DBD dewasa, baik secara klinis maupun secara laboratorik (dengan parameter hitung trombosit).

\section{METODE}

\section{Desain, Tempat, dan Waktu}

Penelitian prospektif ini dilakukan di RSKB (Rumah Sakit Karya Bhakti) dari bulan Mei 2009 hingga Oktober 2009. Penelitian baru dilakukan setelah mendapatkan persetujuan dari Panitia Etik FKUI.

\section{Jumlah dan cara Pemilihan Subjek}

Subjek yang dilibatkan dalam penelitian ini berjumlah 84 orang yang terdiri atas 42 subjek laki-laki dan 42 subjek perempuan. Subjek penelitian dipilih dengan metoda consecutive sampling, berdasarkan diagnosis yang sesuai dengan kriteria WHO 1997, serta memenuhi kriteria inklusi sebagai berikut: demam hingga 7 hari, serologi Dengue Ig $M(+)$ atau NS1 positif, Trombosit $<100.000 / \mathrm{mm}^{3}$, IMT laki-laki antara 20.2 - 27 dan perempuan antara 18.9 - 25.2, tidak menderita penyakit dengan gangguan fungsi imun (Tuberkulosis, Diabetes Melitus Tipe2, sirosis hepatis atau gagal ginjal kronik), nilai SGOT/SGPT dalam batas normal, dan bersedia ikut penelitian dan menandatangani informed consent.

Kriteria eksklusi subjek adalah sebagai berikut: wanita hamil, menderita penyakit TBC, DM, sirosis hepatis, gagal ginjal kronik, dan mengalami sindroma SRD.

Pasien rawat inap yang memenuhi kriteria seperti di atas ditawari untuk ikut dalam penelitian. Hanya subjek yang telah menandatangani informed consent yang diikutsertakan sebagai subjek penelitian. Selanjutnya subjek dirandomisasi ke dalam dua kelompok (pok), yaitu pok perlakuan dan pok kontrol, lalu kegiatan penelitian dilakukan secara paralel.

\section{Bahan}

Bahan intervensi untuk pok perlakuan adalah CGF $40 \%$. CGF yang diberikan merupakan produk yang dibuat dari ganggang air tawar, lalu diekstrak guna memanen derivat 
asam nukleat dari sel-sel yang telah dikeringkan sebelumnya dengan air panas $\left(80^{\circ} \mathrm{C}\right)$. Selanjutnya substansi yang kaya akan asam nukleat serta asam amino tersebut dipisahkan dari residu padatnya dengan sentrifugasi, untuk selanjutnya supernatan yang dihasilkan kemudian disaring dengan metode mikrofiltrasi (Steenblock, 1994).

\section{Prosedur Kerja}

Saat masuk pasien diperiksa oleh dokter poliklinik jaga atau dokter spesialis penyakit dalam, meliputi pemeriksaan fisik dan laboratorium, seperti $\mathrm{Hb}, \mathrm{Ht}$, trombosit, IgM anti DEN/NS1, ureum, GOT, GPT, dan Prot T/A/G. Selanjutnya di ruang rawat inap dokter spesialis yang merawat melakukan pemeriksaan lanjut. Bila diperlukan roentgen thorax PA harus dilaksanakan sesuai tujuan diagnostik dan penentuan keikut-sertaan dalam penelitian.

Kedua kelompok mendapat perawatan rumah sakit standar. Selama penelitian pok perlakuan mendapat bahan intervensi CGF $40 \%$ dengan dosis $1 \times 30 \mathrm{ml}$ per hari, serta terapi standar yang dianjurkan WHO (1997). Di lain pihak pok kontrol hanya mendapat terapi stan- dar saja. Pemeriksaan trombosit, hemoglobin dan hematokrit dilakukan setiap hari. Bila kemudian disertai pula oleh penyakit infeksi lain seperti demam tifoid, selain mendapat terapi standar perlu pula mendapat tambahan antibiotik ciprofloxasin.

Henti rawat atau pengakhiran penelitian dilakukan jika tercapai kondisi klinik dan laboratorik yang memenuhi kriteria pemulangan subjek dari RS, atau pasien jatuh ke dalam DBD berat atau SRD yang ditentukan oleh dokter spesialis penyakit dalam yang merawat. Kriteria laboratorik pemulangan subjek adalah bebas dari simtom dan gejala DBD serta pencapaian jumlah trombosit lebih dari $100.000 / \mathrm{mm}^{3}$.

\section{Pengolahan dan Analisis Data}

Hasil penelitian dianalisis dengan cara intention to treat. Data yang berhasil dikumpulkan diolah dengan menggunakan software SPSS 16, dengan $\mathrm{p}<0.05, B=20 \%$ dan power $80 \%$. Pengukuran yang dilakukan menggunakan skala numerik, dengan demikian uji statistik dilakukan dengan menggunakan uji $t$.

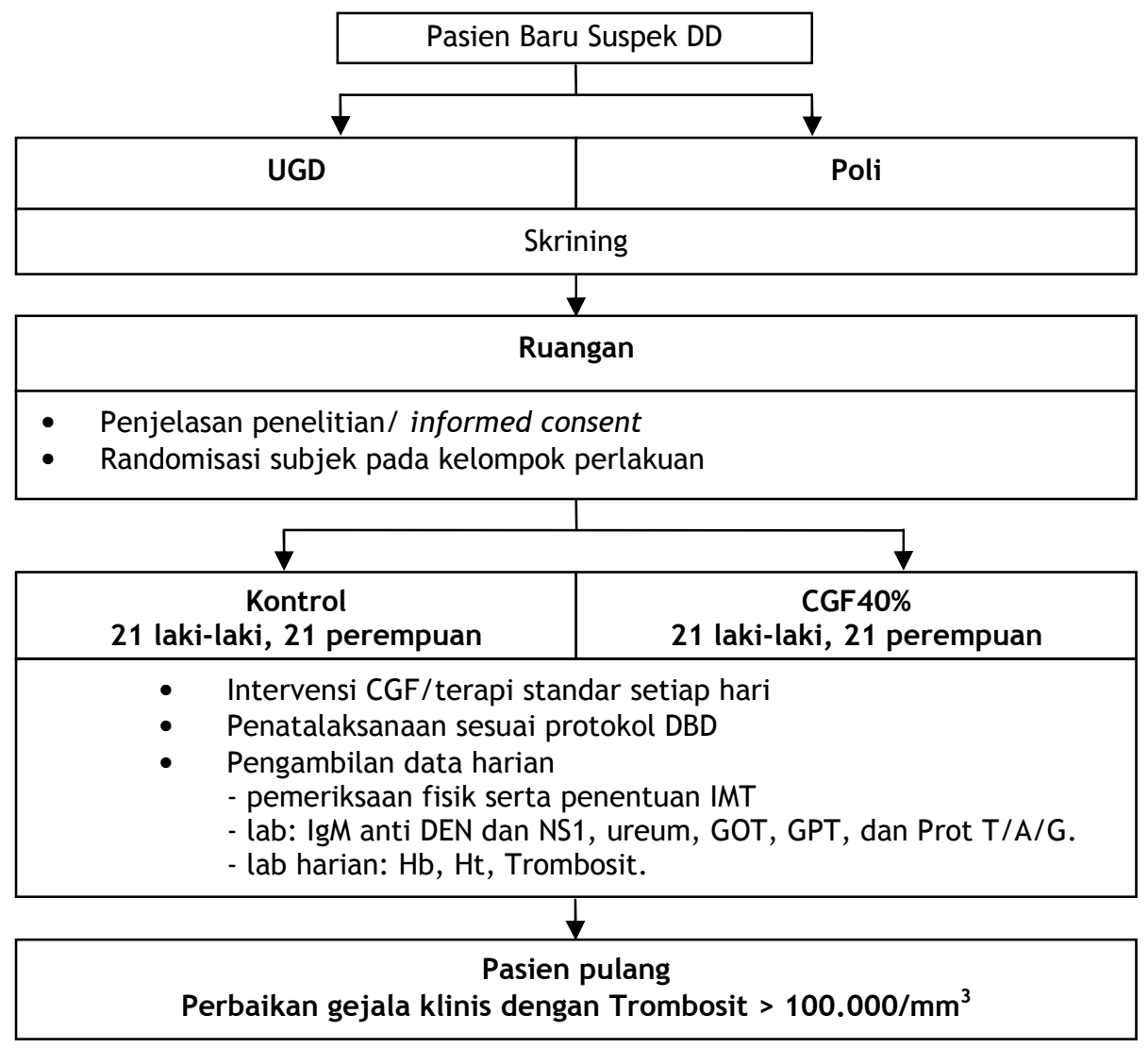

Gambar 1. Alur Pengambilan Data Penelitian 


\section{HASIL DAN PEMBAHASAN}

Sejumlah 84 subjek berhasil diikutsertakan dalam penelitian hingga akhir. Dari jumlah tersebut terdapat sebanyak 42 perempuan dan 42 pria yang kemudian diacak secara berimbang ke dalam dua kelompok, yaitu pok perlakuan dan pok kontrol. Rata-rata usia pada pok perlakuan adalah 26.21 tahun dan pok kontrol 30.05 tahun $(p=0.068)$. Frekuensi jumlah subjek pada pok perlakuan menurut kelompok usia 17 - 25 tahun (27.4\%) lebih besar bila dibandingkan dengan pok kontrol (19\%). Sebaliknya bila ditilik menurut kelompok usia > 26 tahun, frekuensi pada pok perlakuan (22.6\%) lebih kecil dari pada pok kontrol (31\%).

Tabel 1. Distribusi Kasus Dengue menurut Kelompok Usia

\begin{tabular}{lcc}
\hline Kelompok Usia & Perlakuan & Kontrol \\
\hline $17-25$ tahun & $23(27.4 \%)$ & $16(19 \%)$ \\
$>26$ tahun & $19(22.6 \%)$ & $26(31 \%)$ \\
\hline
\end{tabular}

Indeks masa tubuh (IMT) pada pok perlakuan sebesar 19.84 dan pok kontrol 21.86. Lama demam sebelum masuk perawatan masing-masing 4.48 hari bagi pok perlakuan dan 4.45 hari bagi pok kontrol $(p=0.932)$.

Tabel 2. Lama Demam Sebelum Masuk Masa Perawatan

\begin{tabular}{crr}
\hline $\begin{array}{c}\text { Lama Demam } \\
\text { Sebelum Masuk } \\
\text { Perawatan (hari) }\end{array}$ & Perlakuan & Kontrol \\
\hline 2 & 3 & 1 \\
3 & 6 & 9 \\
4 & 10 & 13 \\
5 & 17 & 13 \\
$>5$ & 6 & 6 \\
\hline
\end{tabular}

Jumlah subjek dengan lama demam sebelum masuk perawatan $>3$ hari dijumpai sebanyak 78 orang (95.2\%), dan angka tersebut ternyata lebih besar bila dibandingkan dengan yang lama demam $<3$ hari sebanyak 4 orang $(4.8 \%)$.

Jumlah penderita dengan trombosit awal $<50000$ ketika masuk perawatan pada pok perlakuan adalah 23 (27.4\%) dan pada pok kontrol 10 (11.9\%). Di lain pihak jumlah penderita dengan trombosit awal $\geq 50000$ pada pok perlakuan 19 (22,6\%) dan pok kontrol 32 (38.1\%). Pok perlakuan memiliki jumlah trombosit yang lebih sedikit bila dibandingkan dengan pok kontrol, dengan $\mathrm{p}=0.034$.

Lama penyembuhan bagi pok perlakuan adalah 2.76 hari yang ternyata lebih pendek bila dibandingkan dengan pok kontrol yang berdurasi 4.43 hari, dengan $p=0.000$. Lama penyembuhan pada pok perlakuan dengan trombosit $<50000$ serta $>50000$ masing-masing 3.09 dan 2.37 hari, yang terbukti lebih pendek bila dibandingkan dengan pok kontrol yang lamanya masing-masing 4.2 dan 4.5 hari, dengan a secara berturut-turut sebesar 0.016 dan 0.000 .

Tabel 3. Data Dasar

\begin{tabular}{|c|c|c|c|}
\hline & Perlakuan & Kontrol & \\
\hline \multirow[t]{2}{*}{$\begin{array}{l}\text { Jumlah pasien } \\
\text { dengan jumlah } \\
\text { trombosit saat } \\
\text { masuk perawatan } \\
\text { inap } \\
\quad<25.000\end{array}$} & & & \\
\hline & $9(10.7 \%)$ & $3(3.6 \%)$ & \\
\hline $25.000-49.000$ & 14 (16.7\%) & 7 (8.3\%) & \\
\hline $50.000-74.000$ & $9(10.7 \%)$ & 15 (17.9\%) & \\
\hline $75.000-99.000$ & 10 (11.9\%) & 17 (20.2\%) & $p=0.034$ \\
\hline \multicolumn{4}{|l|}{$\begin{array}{l}\text { Lama } \\
\text { penyembuhan } \\
\text { dengan } \\
\text { trombosit awal }\end{array}$} \\
\hline$<50.000$ & 3.09 hari & 4.20 hari & $p=0.016$ \\
\hline$>50.000$ & 2.37 hari & 4.50 hari & $p=0.000$ \\
\hline \multicolumn{4}{|l|}{$\begin{array}{l}\text { Lama perawatan } \\
\text { pada pok } \\
\text { perlakuan } \\
\text { dengan } \\
\text { trombosit awal }\end{array}$} \\
\hline$<50.000$ & 2.37 hari & & \multirow{2}{*}{$p=0.112$} \\
\hline$>50.000$ & 3.09 hari & & \\
\hline \multicolumn{4}{|l|}{$\begin{array}{l}\text { Lama } \\
\text { penyembuhan } \\
\text { pasien dengan } \\
\text { kadar GPT awal }\end{array}$} \\
\hline$<80$ & 3.16 hari & 4.58 hari & $p=0.001$ \\
\hline$>80$ & 2.18 hari & 4.22 hari & $p=0.000$ \\
\hline $\begin{array}{l}\text { Lama perawatan } \\
\text { di Rumah Sakit }\end{array}$ & 2.76 hari & 4.43 hari & $p=0.000$ \\
\hline
\end{tabular}

Bila ditelaah lebih lanjut pada pok perlakuan, lama perawatan pada subjek dengan trombosit awal <50 000 diperoleh sebesar 2.37 hari. Lama penyembuhan tersebut ternyata lebih cepat bila dibandingkan dengan subjek yang trombosit awal > 50000 sebesar 3.09 hari, $\mathrm{p}=0.112$.

Dalam pola kenaikan trombosit terdapat perbedaan antara pok kontrol dan pok perlakuan. Pada pok kontrol kenaikan trombosit tidak lantas begitu saja meningkat ketika diberikan terapi standar, namun terlebih dahulu diawali dengan penurunan trombosit dari 62758 (hari 0) menjadi 53260 (hari 1) dan baru mulai meningkat menjadi 56196 (hari 3), sesuai dengan persamaan $Y=62758-15715 X+$ $6217 X^{2}\left(R^{2}=0.938\right)$. Sedangkan pada pok perlakuan, kenaikan trombosit terlihat dalam garis 
lurus sesuai dengan persamaan $Y=43911+$ 19298X - 924X $X^{2}\left(R^{2}=0.897\right)$ sejak diberikan CGF.

Pola penurunan, baik kadar hemoglobin maupun hematokrit, di antara kedua kelompok yang diteliti dijumpai berbeda. Dengan uji regresi kuadratik penurunan kadar hemoglobin pada pok kontrol tampak lebih lamban, sesuai dengan persamaan regresi $Y=14.664-0.279 X$ - $0.004 X^{2}\left(R^{2}=0.971\right)$. Kurva penurunan kadar $\mathrm{Hb}$ tergambar dalam garis lurus, dari $14.664 \mathrm{~g} \%$ menjadi $14.381 \mathrm{~g} \%, 14.09 \mathrm{~g} \%, 13.683 \mathrm{~g} \%$ dan seterusnya. Sedangkan penurunan $\mathrm{Hb}$ pada pok perlakuan tampak lebih cepat dan progresif, khususnya pada awal pengobatan dari hari 0 hingga hari 3 , dan baru kemudian untuk seterusnya bergerak stabil sesuai persamaan regresi $Y=14.693-0.922 X+0.125 X^{2}\left(R^{2}=0.998\right)$.

Pola penurunan hematokrit pada pok perlakuan dan pok kontrol juga terlihat berbeda (lihat grafik di bawah). Pada pok kontrol, sesuai dengan persamaan regresi kuadratik $\mathrm{Y}=$ $42.636-0.865 X+0.039 X^{2}\left(R^{2}=0.930\right)$, bentuk kurva penurunan tergambar dalam garis lurus serta berlangsung lebih lamban, mulai dari $42.636 \%$, 42.161\%, 41.022\%, 40.392\% hingga $39.800 \%$.

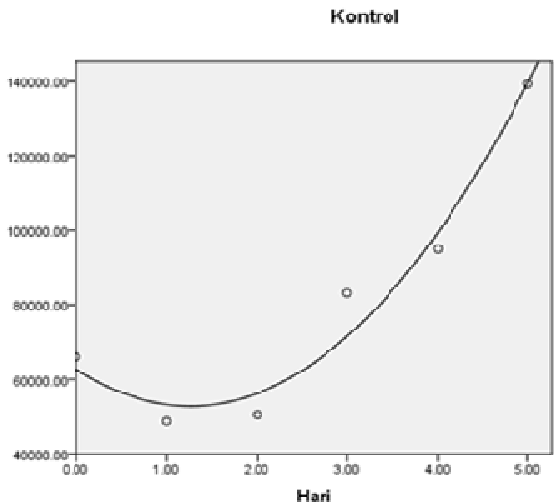

Regresi Kuadratik Peningkatan Trombosit Pok Kontrol.

$Y=62758-15715 X+6217 x^{2}$ $R=0,939 ; \mathbb{R}^{2}=0,963$.

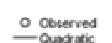

- ountax

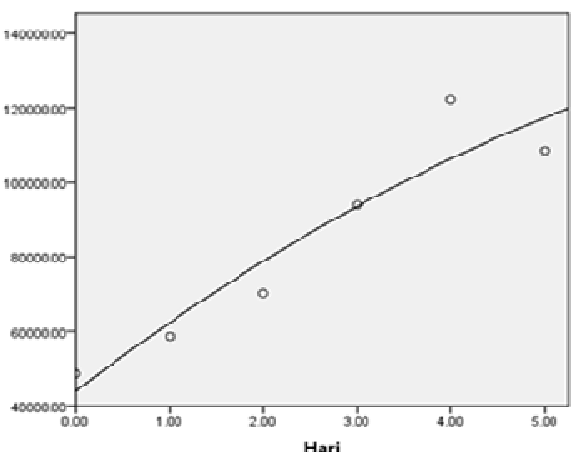

Regresi Kuadratik Peningkatan Trombosit Pok Perlakuan.

$r=43911-19298 x-924 X^{2}$ $\mathrm{R}=0,878 ; \mathrm{R}^{2}=0,897$.

Gambar 2. Grafik Peningkatan Trombosit

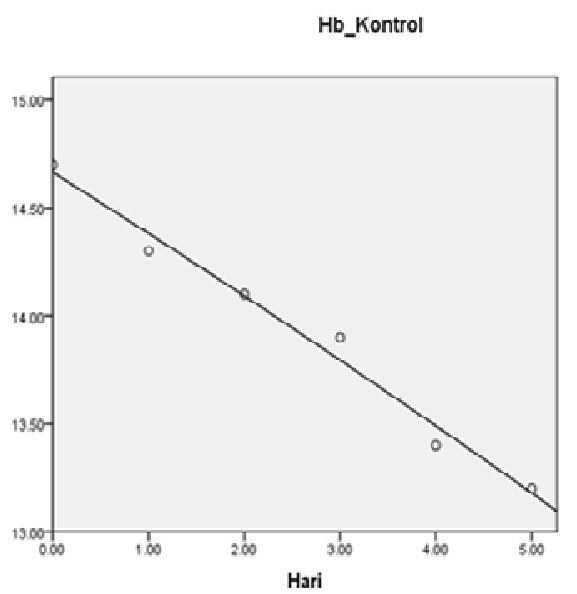

Regresi Kuadratik Penurunan Hemoglobin Pok Kontrol,

$Y=14.664 \quad 0.279 \times \quad .004)^{2}$ $\mathrm{R}=0,982 ; R^{2}=0,971$
Hb_Perlakuan
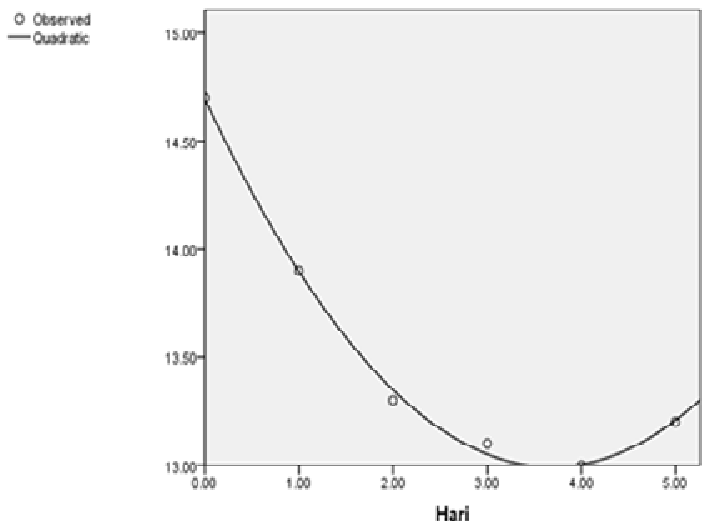

- Observed

Regresi Kuadratik Penurunan Hemoglobin Pok Perlakuan.

$Y=14.693 \quad 0.922 X+0.125 \times 2$ $R=0,996 ; R^{2}=0,998$.

Gambar 3. Grafik Penurunan Hemoglobin 


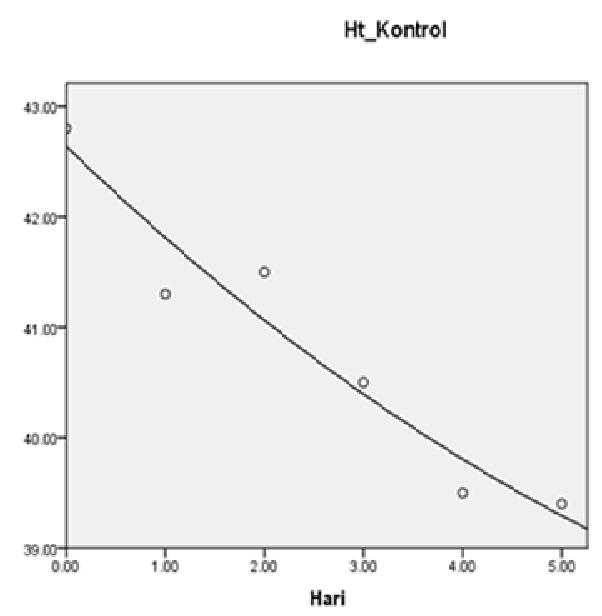

Regresi Kuadratik Penurunan Hematokrit Pok Kontrol.

$$
\begin{gathered}
r=42,636-0,865 x+3,039 \times x^{2} . \\
F=3,883 ; R^{2}=0,930 .
\end{gathered}
$$

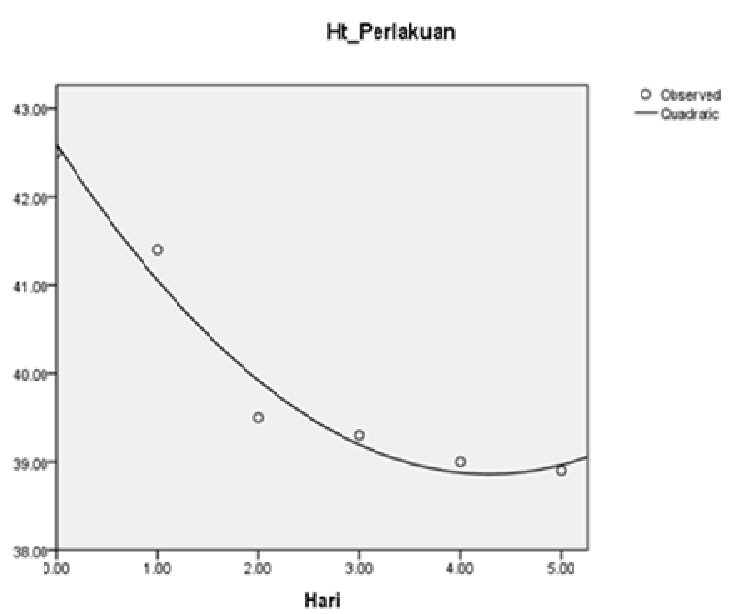
Regresi Kuadratik Penurunan Hematokrit Pok Perlakuan.
$Y=42,593-1,74<x+0,204 X^{2}$. $R=0,950 ; R^{2}=0,970$.

Gambar 4. Grafik Penurunan Hematokrit

Pada pok perlakuan penurunan hematokrit berlangsung sesuai dengan persamaan regresi kuadratik, $Y=42.593-1.744 X+0.204 X^{2}$ $\left(R^{2}=0.970\right)$. Dalam tiga hari pertama kurva penurunan tampak lebih cepat bila dibandingkan dengan pok kontrol, mulai dari 42.593\%, $41.053 \%$, 39.921\%, 39.197\% hingga akhirnya $38.881 \%$, dan baru kemudian untuk selanjutnya berlangsung mendatar.

Lama penyembuhan pada pok perlakuan dan pok kontrol dengan kadar GPT <80, masing-masing sebesar 3.16 hari dan 4.58 hari $(p=0.001)$. Sedangkan pada kadar GPT $>80$ lama penyembuhan untuk masing-masing kelompok sebesar 2.18 hari dan 4.22 hari $(p=0.000)$. Artinya pada tingkat morbid yang lebih berat sekalipun pemberian CGF pada pok perlakuan tetap menunjukkan tingkat kecepatan penyembuhan yang lebih baik.

Hingga kini obat anti virus yang dapat digunakan untuk terapi kausal DD belum tersedia. Oleh sebab itu tata-laksana DD, sesuai dengan anjuran WHO, diarahkan pada penggantian cairan tubuh yang hilang, mengatasi demam tinggi, mengoreksi gangguan elektrolit dan metabolik, mengantisipasi timbulnya renjatan dan DIC (disseminated intravascular coagulation), serta memastikan asupan makanan yang cukup gizi.

Status gizi yang baik adalah faktor utama yang diperlukan untuk memperoleh tingkat regenerasi sel optimal. Sejauh ini diketahui bahwa status gizi kurang berkaitan dengan kapasitas imunoregulatoris sel. Pada hal penderita dengan baik DD maupun DBD terbukti memiliki tingkat imunoregulatoris yang kurang memadai (Wahid et al., 2000). Lebih lanjut pada kondisi morbid pada DD terjadi penurunan nafsu makan, mual dan muntah yang tentunya mempersulit pemenuhan kebutuhan gizi secara kualitas dan kuantitas. Oleh sebab itu faktor gizi yang berperan sentral dalam patologi penyakit DD perlu disikapi, khususnya guna memperoleh status gizi yang mumpuni.

Pemberian suplemen makanan untuk melengkapi kebutuhan gizi guna memfasilitasi regenerasi sel yang optimal dalam jangka pendek merupakan pilihan alternatif. Sejalan dengan pandangan tersebut serta sesuai dengan hasil pengamatan Dr. Michinori Kimura, ganggang chlorella yang telah terbukti kaya akan derivat asam nukleat DNA/RNA, Chlorella Growth Factor (CGF) serta asam amino esensial dapat dipertimbangkan. Chlorella Growth Factor (CGF) diketahui potensial mempromosikan pertumbuhan sel lebih cepat melalui mekanisme peningkatan fungsi RNA/DNA. CGF mendorong optimalisasi sintesis protein, enzim dan energi pada tingkat seluler. Di samping itu CGF merangsang perbaikan sel-sel dan jaringan dari kerusakan serta, meningkatkan sistem imun. Apabila dikonsumsi secara reguler CGF bermanfaat untuk memperbaiki materi genetik sel-sel manusia yang rusak, sehingga dapat digunakan sebagai obat untuk tujuan regenerasi sel-sel tubuh yang rusak (Anonim, 2009). 
Patofisiologi marka utama DD (hemokonsentrasi, trombositopenia dan tes torniquette positif) sangat tergantung ke pada perembesan plasma akibat peningkatan permeabilitas vaskuler (vaskulopatia) yang disebabkan oleh infeksi sekunder VDEN (Basu \& Chaturvedi, 2008; Cabello-Gutiérrez etal., 2009). Pada tingkat awal dampak dari permeabilitas vaskuler secara klinis berupa hemokonsentrasi. Apabila tak cepat diatasi peningkatan permeabilitas vaskuler tersebut potensial berkembang menimbulkan renjatan, yang secara definitif merupakan fondamen patologis bagi timbulnya gangguan funksi trombosit, konsumtif koagulopatia serta akhirnya disseminated intravascular coagulation (DIC) (Chen et al., 2009).

Timbulnya trombositopenia diduga akibat faktor-faktor penekanan pada fungsi produksi sumsum tulang (Noisakran et al., 2009) serta fagositosis trombosit (DeCastro et al., 2007), yang disebabkan oleh mekanisme imun (Saito et al., 2004), akselerasi fagositosis trombosit (Honda et al., 2009) dan stress oksidatif (Soundravally et al., 2008). Tingkat trombositopenia dilaporkan berkorelasi dengan beratnya vaskulopatia serta peningkatan GPT (Mourão et al., 2007).

Telah lama diketahui infeksi VDEN dapat menimbulkan peningkatan GPT (Wahid et al., 2000). Tampaknya peningkatan GPT tersebut diakibatkan oleh dampak dari peningkatan permeabilitas vaskuler (Mourão et al., 2007) serta timbulnya reaksi tidak khas dari infeksi VDEN itu sendiri pada hepar (Pancharoen, Rungsarannont \& Thisyakorn, 2002; Souza et al., 2004; Larreal et al., 2005; Wiwanitkit, 2007).

Pada penelitian ini status gizi baik pada pok perlakuan maupun pok kontrol masingmasing berada pada tingkatan berat badan kurang $\left(19.84 \mathrm{~kg} / \mathrm{m}^{2}\right)$ dan berat badan normal rendah $\left(21.86 \mathrm{~kg} / \mathrm{m}^{2}\right)$, mengingat status gizi yang normal bergerak pada kisaran 18.5 - 24.9 $\mathrm{kg} / \mathrm{m}^{2}$. Pemberian CGF di sini jelas ditujukan untuk meningkatkan proses reparasi fungsi sel endothelium vaskuler, memacu fungsi produksi sumsum tulang, ketahanan tubuh serta menekan stress oksidatif dalam konsep kedokteran regeneratif.

Pada penelitian ini pemberian CGF ke pada kelompok perlakuan terbukti memperpendek masa perawatan di rumah sakit (2.76 hari) secara bermakna $(p=0.000)$. Pada hal jumlah trombosit ketika masuk perawatan pada pok kelompok yang mendapat terapi CGF lebih rendah bila dibandingkan dengan pok kontrol. Bila dicermati lebih lanjut pada kelompok yang mendapat terapi CGF, lama penyembuhan pada mereka yang memiliki jumlah trombosit awal $(<50000)$ dijumpai lebih pendek dari pada mereka yang trombosit awalnya (>50 000), namun demikian secara statistik tidak berbeda nyata $(p=0.112)$. Begitu pula bila dicermati lebih lanjut pada mereka yang memiliki kadar GPT baik [ $<80 \mathrm{IU} / \mathrm{L}$ ] maupun [ $>80$ IU/L], kelompok yang mendapat terapi CGF lebih cepat sembuh secara bermakna $(p=0.001$ dan 0.000).

Pemberian CGF pada penelitian ini tampak memberikan warna tersendiri pada pola kenaikan trombosit, penurunan kadar hemoglobin serta hematokrit. Pada mereka yang mendapat terapi CGF, pola kenaikan trombosit tampak lebih progresif dan cepat. Di lain sisi pada mereka yang mendapat terapi standar gambaran yang diperoleh tampak lebih lamban, bahkan pada awal terapi didahului oleh penurunan jumlah trombosit, dengan $R^{2}$ nyaris mendekati 1. Artinya, pemberian CGF mampu merangsang fungsi produksi sumsum tulang, mencegah perusakan trombosit serta menekan stress oksidatif yang ditimbulkan oleh infeksi VDEN.

Begitu pula pola penurunan hemoglobin dan hematokrit pada mereka yang mendapat CGF terlihat lebih cepat dan progresif bila dibandingkan dengan mereka yang mendapat terapi standar. Gambaran demikian jelas menunjukkan perbaikan dalam aspek hemokonsentrasi yang disebabkan oleh infeksi VDEN. Dengan demikian CGF di sini dapat memperbaiki gangguan vaskulopatia yang diakibatkan oleh peningkatan permeabilitas vaskuler akibat infeksi VDEN.

\section{KESIMPULAN}

Pada penelitian ini terbukti bahwa CGF mampu memperagakan konsep regenerative medicine secara bermakna, dengan cara mempercepat waktu penyembuhan, merangsang peningkatan fungsi produksi sumsum tulang, menekan stress oksidatif, dan memperbaiki gangguan vaskulopatia akibat peningkatan permeabilitas vaskuler akibat infeksi VDEN.

Mengingat belum adanya obat virusid yang tersedia, sewajarnya promosi kesehatan ditegaskan sebagai salah satu upaya pencegahan DD, dengan cara meningkatkan status gizi setiap insan yang hidup di daerah endemis dapat ditingkatkan sehingga kelak diharapkan berperan meredam keganasan VDEN. Pembe- 
rian suplemen makanan dalam hal ini tentu merupakan pilihan yang bijak. Perlu adanya penelitian lanjut dalam aspek biomolekuler guna menguji efektivitas CGF dalam menangkal virulensi serotype DEN2 dan DEN.

\section{UCAPAN TERIMA KASIH}

Pada kesempatan ini para peneliti mengucapkan terima kasih ke pada Dr. Mismasdi Mihad, selaku Direktur RS Karya Bhakti Bogor, beserta para staf direksi RS Karya Bhakti Dr. Bambang Soebianto, SpS, Dr. Hadian Setia, SpB dan Dr. Eko, MBA. Begitu pula ucapan terima kasih ditujukan ke pada Dr. Maria, para dokter jaga beserta para perawat RS Karya Bhakti Bogor yang telah membantu dalam menyelesaikan penelitian ini. Tak lupa pula kami mengucapkan terima kasih kepada Dekan Fakultas Ekologi Manusia, IPB Bogor Prof. Dr. Ir. Hardinsyah, Ir. Bambang, MS, dan Ibu Lingke Tirtakencana SE beserta staf direksi PT CNI Indonesia. Akhirnya tak lupa pula kami mengungkapkan rasa hormat kami yang setinggitingginya kepada para pasien yang bersedia menjadi relawan untuk diteliti. Tanpa bantuan yang tulus dan ikhlas dari mereka yang kami sebut di atas rasanya tak mungkin penelitian ini dapat dilaksanakan.

\section{DAFTAR PUSTAKA}

Anonim. 2009. Emedicine Web site [http:// www.emedicine.com/emerg/topic124.h $\mathrm{tm}]$.

Anonim. 2009. Chlorella growth factor. http:// www. naturalways.com/chlorella-growthfactor.htm.

Basu A \& Chaturvedi UC. 2008. Vascular endothelium: the battlefield of dengue viruses. FEMS Immunol Med Microbiol, 53: 287-99.

Burke DS et al. 1988. A prospective study of dengue infections in Bangkok. Am J Trop Med Hyg, 38:172-80.

Cabello-Gutiérrez C, Manjarrez-Zavala ME, Huerta-Zepeda A, Cime-Castillo J, Monroy-Martínez V, Correa BB, \& RuizOrdaz BH. 2009. Modification of the cytoprotective protein C pathway during Dengue virus infection of human endothelial vascular cells. Thromb Haemost. 101(5): 916-28.
Chen LC, Shyu HW, Lin HM, Lei HY, Lin YS, Liu HS, \& Yeh TM. 2009. Dengue virus induces thrombomodulin expression in human endothelial cells and monocytes in vitro. J Infect. 58(5): 368-74.

DeCastro RAC, De Castro JAA, Barez MYC, Frias MV, Dixit J \& Genereux M. 2007. Thrombocytopenia Associated With Dengue Hemorrhagic Fever Responds To Intravenous Administration of Anti-D (Rho-D) Immune Globulin. Am J Trop Med Hyg, 76 (4): 737-42.

Guzman MG \& Kouri G. 2002. Dengue: an update. Lancet Infect Dis, 2: 33-42.

Honda S, Saito M, Dimaano EM, Morales PA, Alonzo MT, Suarez LA, Koike N, Inoue S, Kumatori A, Matias RR, Natividad FF, \& Oishi K. 2009. Increased phagocytosis of platelets from patients with secondary dengue virus infection by human macrophages. Am J Trop Med Hyg. 80(5): 8415 .

Kuo MC, Chang JM, Lu PL, Chiu YW, Chen HC, \& Hwang AJ. 2007. Case Report: Difficulty in Diagnosis and Treatment of Dengue Hemorrhagic Fever in Patients with Chronic Renal Failure: Report of Three Cases of Mortality. Am. J. Trop. Med. Hyg. 76(4): 752-56.

Larreal Y, Valero N, Estévez J, Reyes I, Maldonado M, Espina LM, Arias J, Meleán E, Añez G, \& Atencio R. 2005. Hepatic alterations in patients with dengue. Invest Clin. 46(2): 169-78.

Mourão MP, Lacerda MV, Macedo VO, \& Santos JB. 2007. Thrombocytopenia in patients with dengue virus infection in the Brazilian Amazon. Platelets. 18(8): 60512.

Noisakran S, Chokephaibulkit K, Songprakhon $P$, Onlamoon $\mathrm{N}$, Hsiao $\mathrm{HM}$, Villinger $\mathrm{F}$, Ansari A, \& Perng GC. 2009. A reevaluation of the mechanisms leading to dengue hemorrhagic fever. Ann N Y Acad Sci. 1171 Suppl 1: E24-35.

Pancharoen C, Rungsarannont A, \& Thisyakorn U. 2002. Hepatic dysfunction in dengue patients with various severity. J Med Assoc Thai, 85 (Suppl 1): S298-S301. 
Porter KR, Beckett CG, Kosasih H, Tan RI, Alisyahbana B, Rudiman PIF et al. 2005. Epidemiology of Dengue and Dengue Hemorrhagic Fever in a Cohort of Adults Living in Bandung, West Java, Indonesia. Am. J. Trop. Med. Hyg. 72(1): 60-66.

Rigau-Perez JG, Clark GG, Gubler DJ, Reiter P, Sanders EJ \& Vorndam AV. 1998. Dengue and dengue haemorrhagic fever. Lancet, 352: 971-77.

Saito $M$, Oishi K, Inoue S, Dimaano EM, Alera MT, Robles AM, Estrella BD Jr, Kumatori A, Moji K, Alonzo MT, Buerano CC, Matias RR, Morita K, Natividad FF, \& Nagatake T. 2004. Association of increased platelet-associated immunoglobulins with thrombocytopenia and the severity of disease in secondary dengue virus infections. Clin Exp Immunol 138: 299-303.

Soundravally R, Sankar P, Bobby Z, \& Hoti SL. 2008. Oxidative stress in severe dengue viral infection: association of thrombocytopenia with lipid peroxidation. Platelets. 19(6): 447-54.
Souza LJ, Alves JG, Nogueira RM, Gicovate Neto C, Bastos DA, Siqueira EW, Souto Filho JT, Cezário Tde A, Soares CE, \& Carneiro Rda C. 2004. Aminotransferase changes and acute hepatitis in patients with dengue fever: analysis of 1,585 cases. Braz J Infect Dis. 8(2): 156-63.

Steenblock D. 1994. Chlorella, Makanan Sehat Alami. PT Gramedia Pustaka Utama, Jakarta

Wahid SF, Sanusi S, Zawawi MM, \& Ali RA. 2000. A comparison of the pattern of liver involvement in dengue hemorrhagic fever with classic dengue fever. Southeast Asian J Trop Med Public Health. 31(2): 259-63.

[WHO] World Health Organization. 1997. Dengue haemorrhagic fever: diagnosis, treatment, prevention and control, 2nd edn. Geneva.

Wiwanitkit V. 2007. Liver Dysfunction In Dengue Infection, An Analysis of The Previously Published Thai Cases. J Ayub Med Coll Abbottabad, 19(1): 10-12. 